\title{
Islam and Contemporary Society: Emerging Paradigms to Explain Muslim Communities
}

\author{
Muhammad Rehan Masoom ${ }^{1, a^{*}}$ \\ ${ }^{1}$ Assistant Professor, School of Business and Economics, \\ United International University, Bangladesh. \\ E-mail address: ${ }^{a}$ rehan_1611@yahoo.com
}

Keywords: Islam, Islamism, Jihad, Suicide Bombing, Politics

\begin{abstract}
There is hardly any country, where most of the people do not follow a particular religious view, but no other religious groups need to address so many controversies as the Muslims do. Islam is no more merely a religion; it is a political agenda, a manifestation of orthodoxy, an enticement to establish particular ideology and many more. Islam has integrated a variety of political and social facet into it; hence diversity in comprehension emerged. Various scholars analyzed numerous aspects of Islam. This paper attempts to narrate the most imperative aspects of Islam in the modern day and tries to delineate the significant role that Islam plays in the life and living of individuals of all around the world.
\end{abstract}

\section{INTRODUCTION}

There are more than million religious sects around the world and it is impossible to predict the exact of religions exists today. Some small, isolated religious cults can also be counted as a fully developed religion. However, Christianity, Islam, Hindism and Buddhism are the four religious beliefs that predominantly prevail around the world. Notably, the numbers of Christians are much higher than that of the Muslims, but the word, 'Islam' is more popular than any other word related to any religion. If anyone searches by this word with the world's most popular search engine, google.com it would yield 374 million results of entities, whereas the same search engine will yield slightly over 104 million for the word Christianity, a little more than 119 million for Hinduism and some 43 million for Buddhism. This clearly indicates the popularity of Islam as a subject matter.

The study attempts to discuss twelve scholars' notions of Islam; Abdullahi Ahmed An-Na'im, the Charles Howard Candler Professor of Law at Emory University School of Law; Akbar Ahmed, an anthropologist, filmmaker, administrator, diplomat and a Muslim scholar on Islam, International Relations and Politics, and Contemporary Islamic philosophy from Pakistan who is according to the BBC, he is "the world's leading authority on contemporary Islam"; Anna Mansson McGinty, lecturer in

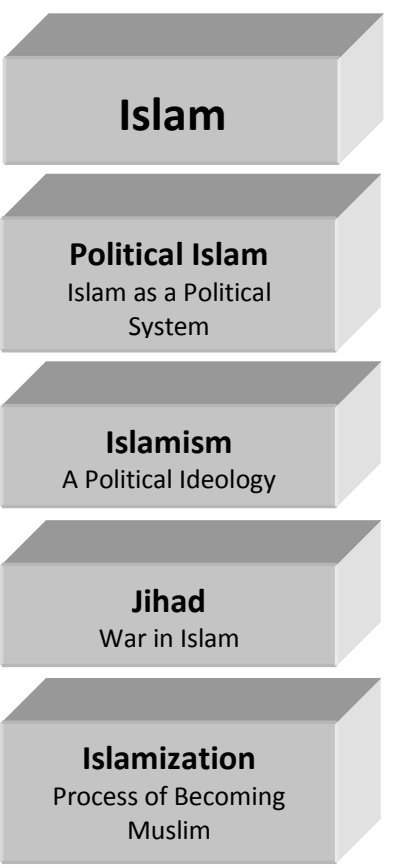

Fig. 1: Concepts related to Islam Anthropology and Women's Studies at University of WisconsinMilwaukee, USA; Anouar Majid, professor of English at the University of New England and a leading figure in examining the place of religion and Islam in postcolonial theory and the culture of globalization; Benjamin Soares, an anthropologist in the African Studies Centre, Leiden; David Cook, Assistant Professor of Religion at Rice University and also one of the world's most broadly knowledgeable scholars of contemporary Islam; Eric S. Ross, a cultural and urban geographer who holds a degree in Islamic Studies; Howard M. Federspiel teaches political science at the Ohio State University; Marc Sageman, a forensic psychiatrist and a counter-terrorism consultant and an independent researcher on terrorism and the founder of Sageman Consulting, LLC; Meghnad 
Jagdishchandra Desai a British economist, writer and Labor politician, Professor Emeritus and an Honorary Associate of the National Secular Society; Mohammed Ayoob, a Distinguished Professor of International Relations at Michigan State University's James Madison College and the Department of Political Science; Mohammed M. Hafez, Visiting Professor in the Department of Political Science at the University of Missouri - Kansas City.

\section{DISCUSSION}

Functions of religion are rather related to the private sphere of life and politics is to the public sphere. However, history shows that they are very much interconnected and influence each other in a number of ways. Scholars attempt to develop some typologies regarding the numerous aspect of Islam as an integrated part of the political system. Three distinct administrative systems can be found among the Muslim countries that are highly related to globalization (Ahemd, 2007). Sometimes, governing bodies of the Muslim world are the religious entrepreneurs who contribute to the commodification and personalization of religion that eventually resulted in giving religious affiliation more value than that of spiritual individualism (Soares, 2005). The constitutions of Muslim countries should be based on Sufi traditions of Islam rather than that of colonial form of constitution to be more effective and for the betterment of the people (An-Na'im, 2006).

Akbar Ahmed (2007) is of interest to the contemporary ideological deformations of the Muslim world. Based on a survey, he presents an assessment of elite opinion in eight Islamic countries, Turkey, Syria, Qatar, Jordan, Pakistan, India, Malaysia and Indonesia to discover the prevailing ideas of the modern Islamic world. His multidisciplinary study heavily relies on interviews and informal surveys of the Muslims. Most of the respondents belong to 18-28 age brackets, male and female, and primarily educated. Ahmed's primary concern is about the models of Islam that he designated in accordance with the names of towns in India: (1) Ajmer, (2) Aligarh, and (3) Deoband. These three cities symbolize distinct interpretations of Islam that are universally applicable. The Ajmer approach is rooted in pluralism, whereas the Aligarh approach advocates parliamentary democracy and the Deoband model is in favor of fundamentalism. Ajmer model is the "only one that can lead Muslims out of the ethnic, religious and political conflicts that globalization has thrust upon them" (Ahmed, 2007:40).

Professor Akbar wishes for a pluralistic, tolerant and cosmopolitan Muslim world and a union of the three Abrahamic faiths. However, during the last three decades the Deoband model replaced both Ajmer and Aligarh. Deobandis inspires thousands of Muslims, particularly the young generations. This very harmful and "the poisons are spreading

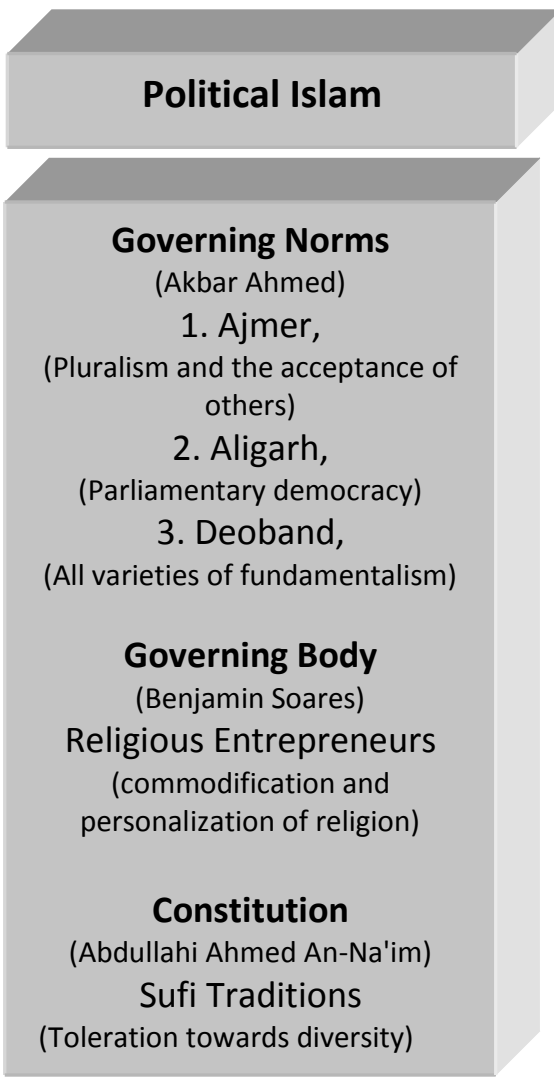

Fig. 2: Islam as a Political System. so rapidly that without immediate remedial action, no antidote may ever be found" (Ahmed, 2007:47). There is an 'asymmetry' between the developed and underdeveloped world and Akbar points this as the underlying cause behind the young Muslims' preference of the extremism. The distress caused by the humiliation of religious symbols and traditions manipulated by the west serves predetermined ideological and political objectives. Ahmed explains the inheriting culture, customs and ideas that are posing an obstacle to the globalization. With this, he discusses much about the refusal of the third world to the globalization. 
The relationship between Islam and administrative authority is the focal point of Benjamin Soares (2005) as well. He discusses about the struggles in Nioro, a city in the south-west of Senegal. Highlighting the diversity, Sores gives a detail description of the increasing commodification and personalization of religion that plays the most crucial role in the formation of authority. People consider the authority as the holy men or saints who act as a media for the divine recompense and people seek benefits from them by providing certain gifts. Thus, class of religious entrepreneurs evolves. That makes religious affiliation more important for doing business, rather than fulfilling a spiritual need. New technologies of print, photography, video and sound recording contribute immensely to profiler this so called 'Prayer Economy'.

Islam sometimes plays a vital role in the formation of the constitution. Abdullahi Ahmed An-Na'im (2006) discusses about African constitutionalism as something that limits political power to ensure the rights and liberties of the people. He contends that by adding the idea of constitutionalism, Eurocentric models can explain Africa. His "inclusive theory of constitutionalism" incorporates the definition and implementation of constitutionalism in colonial and postcolonial circumstances of Africa. An-Na'im considers that precolonial, colonial, and postcolonial stages of Africa are in fact a unified process to construct the constitutional governance. He refers Ghana and Nigeria as the example of the societies as such. An-Na'im helds colonialism as responsible for the lack of successful constitutionalism in Africa. "African populations apparently tended to accept arbitrary and authoritarian government, violations of human rights, and general economic and social hardship as simply the way things are supposed to be" (An-Na'im, 2006:91). He illustrates his thesis by exploring the constitutional experiences of African countries especially Ethiopia, Ghana, Guinea, Rwanda, Tanzania and Uganda. He emphasizes the role of sufi traditions to form modern constitutionalism because they are more tolerable towards the diversity. Muslims of Senegal "withdraw support for any new religious movement if it fails to associate itself with political power" (An-Na'im, 2006:153). His final focus deals with the debate of 'Africanization of Islam' and 'Islamization of Africa' to the dialectic of constitutionalism in Africa and African constitutionalism.

Islamization is a process whereby more people, either by willingly or by force, become Muslim or adopt Islam as their religion. Sometimes, it is termed as Islamification or Muslimization. However, Muslimization is being used to describe, "the overtly Muslim practices of new converts to the religion who wish to reinforce their newly acquired religious identity". These different concepts may refer different events, incidents or actions, but by wider sense, all of these terms confer to the same process of conversion. The process of Islamization is rather a complicated phenomenon as it includes distinct aspects of social life and various dimensions of religiosity. It brings a change by integrating dissimilar religious ideas and diverse rituals under one single religion. Sometimes, it is defined as a gradual, peaceful process of conversion that brings changes in regional political power relations, the formation of state, legal institutions, norms, rituals and religious ideas (Federspiel, 2007). At times, this process merges with urbanization and Islamic symbols, institutions Sufi orders (Ross, 2006). The consequences of Islamization may not always be good, especially among the women who seem to face disparity because of some societal norms (McGinty, 2006).

\section{Islamization}

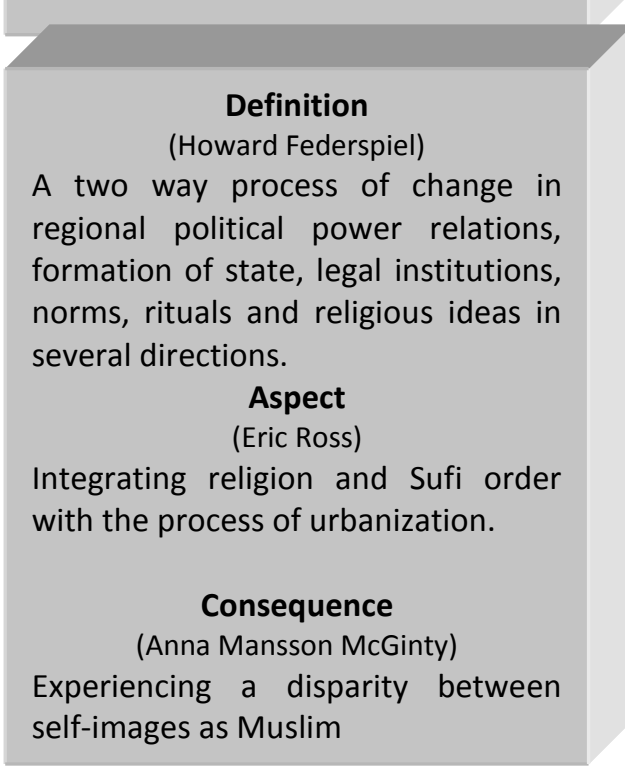

Fig. 3: Islamization 
Federspiel (2007) regards Islamization as a gradual and peaceful process that brings changes in power relations and the formation of religious norms and rituals. By providing a detail account of the thirteen-century transitions of religion, politics, trade and customs in Souteast Asia, he indicates that Islamization was both a flow of people as well as ideas. It was a constantly evolving complex of theological, cultural and social norms that assimilated ideas from other religious traditions as well. A vast range of interaction initially took place between the Muslim merchants and Hindu rulers, hence the commerce was the basic force the have brought the changes in religious institutions and practices. Further, language and laws played a crucial role in this hundreds of years of the conversion process. However, in the recent period of 'independent state consolidation', a rather aggressive way is integrated to reinforce to be connected to fellow the Muslims, who may not only live in different part of the world, but also have different cultural traditions.

The mystical dimension of Islam (Sufism) and urbanization is also inter-linked. Eric Ross (2006) studied a city of Senegal, named Tauba and discussed about the process of urbanization in relation to the practice of Sufi Islam. Though the researcher focuses geography, spiritual, social and political aspects of the city, what is most interesting, is his discussion to integrate religion and the urbanization. The Sufism has a tremendous impact on the people, forces and institutions to build the city, Tauba. He claims that the Muslim agents, French administrative divisions, agricultural practices and railroads contributed to build up the city. He also reckons the process of adaptation of Islamic symbols and institutions to make a clear understanding of the city's development.

Anna Mansson McGinty (2006) discusses the cause and consequences of converting to Muslim in Sweden and the United States. She studies the narratives of nine women, six from Sweden and three from the United States, and analyzes the interviews within a theoretical framework based on psychological anthropology. She considers 'personal models' as her basis of analysis. That includes the personal ideas, emotions and memories that are tied to the subjects' own "biographical idiosyncrasies". Her basic focus is to demonstrate the integration process of new ideas with that of already existing cognitive framework. She termed this as, "cognitive reconciliation". She finds that a sense of spiritual needs led them to become Muslim. Those spiritual needs are the desire for stronger family values, commitment to social justice, aspiration for women's rights and the negative stereotyping of the Muslim. However, these women experience a disparity between their self-images as Muslim. These Swedish women would like to continue to be identified themselves as the "Swedish". It is tantamount to them as the trait that indicates modernity, equality and social justice. Thus, the Muslims are being segregated in the West, even when they are themselves Westerners.

'Islamism' commonly refers to a radical interpretation of Islam aimed at controlling political power with the means of violence. Like other -'ism', (such as fascism, Marxism, Communism or nationalism) 'Islamism' also implies a totalitarian ideology to control the administrative power. 'Islamism' commonly shows less toleration towards the non-Muslims, and a great antagonism towards the West. Islamism is an integration of Islam and politics resulted as consequences of colonial dialectic aimed to use the state as the instrument of Sharia - the Islamic law (Ayoob, 2008). This is also a democratic alternative to authoritarian regimes and can restore the practice of theological-intellectual dissent of Islam, which can oppose the forces of globalization (Majid, 2007). As a political ideology, it has three forms in accordance with the goals, such as aiming to seek a moral regeneration among Muslims - Moral Islamism, making the state as the tenets of Sharia- National Islamism and creating a worldwide Muslim polity with violent actions - Global Islamism. 
Mohammed Ayoob (2008) considers Islamism as political rather than a religious phenomenon and need to be understood within the framework of the nation-state. He de-mystifies political Islam by regarding this as an "invention of tradition". There was no Islamic state before and there is no mention as such in the Holy Quran. Political Islam is monolithic and intrinsically violent. When the development and application of law in Islam occurred within the civil society, the contemporary Islamists contend that the state should be the act of Sharia. This act is actually a departure from traditional Muslim practice. "Islam is no more politicized than Judaism and Christianity." (Ayoob, 2008:14).

Ayoob says that very soon after the death of the Prophet, religion and politics were being separated and the religious establishment was subordinate to temporal authority. Even the present day Arab states, including Saudi Arabia (the 'House of Saud') dictates the institutionalized manifestations of Wahhabism. Thus, in reality, no two Islamism are alike, they are all conditioned by the national contexts within which they originate and operate. The rise of Islamism is the outcome of the colonial dialectic. Colonialism undermined the role of religious scholars, the Ulama and inspired the Islamist scholars. These thinkers had not received any classical training and their primary concern was political rather than religious. Because Islamism arose within specific historical and national contexts, it is very dissimilar, thus "no individual, group or tendency in the contemporary era... can speak authoritatively

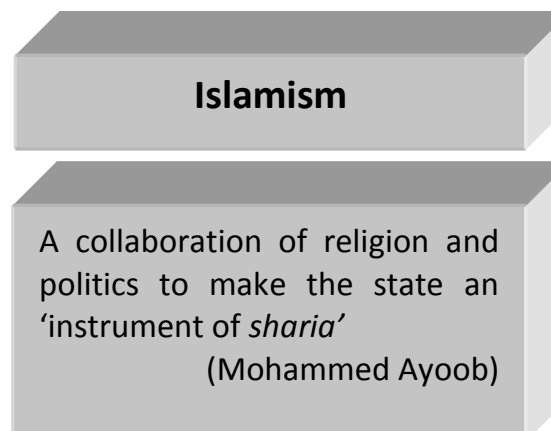

An effective strategy to oppose globalization and a democratic alternative to restore the practice of intellectual and theological dissent of Islam

(Anouar Majid)

A political ideology and a philosophical stand with a set of political goals revealed in three forms: (1) Moral Islamism, (2) National Islamism and (3) Global Islamism.

(Meghnad Desai)

Fig. 4: Islamism on behalf of Muslims, let alone Islam" (Ayoob, 2008:41).

Ayoob undertakes paired case studies of the Muslim world to indicate distinct forms of Islamism. There are (a) self-proclaimed Islamic states (Saudi Arabia and Iran), (b) ideological and pragmatic Islamism (Egypt and Pakistan), (c) Muslim democracies (Turkey and Indonesia), (d) Islamist national resistant (Hamas and Hezbollah), (e) Traditional Islamism (al-Afghani, Tablighi Jamaat, Hizb alTahrir, al-Muhajiroun and al-Qaeda). Saudi Arabia is an anti-constitutional monarchy and Iran is a constitutional republic, a modern construct, not prescribed by Islam. Pakistan nurtured Islamists more committed to democracy than the Egyptian. "Hybridization" occurs and Egypt becomes more militant and Pakistan more moderate. Productive economic globalization occurs in both Turkey and Indonesia. Their export-oriented economies have facilitated the rise of an Islamist bourgeoisie that is a synthesis of globalization and religion. The political objectives of Hamas and Hezbollah are territorially focused and their political Islam is a surrogate national-liberation ideology, which can hardly be contended. Both reflect the "abnormal situations of occupation and state debility - along with the corollary of external intrusion" (Ayoob, 2008:130). Their structural constraints impeded their transformation into political parties. Al-Afghani has both nonviolent and violent forms, whereas al-Qaeda is unlikely to have a lasting impact on Muslim societies. Ayoob presents an argument, the authoritarianism favors the rise of Islamism within oppositions at the expense of secularists and the exercise of U.S power has created the colonial dialectic that stimulates the rise of radical, liberationist Islamism.

Anouar Majid (2007) indicates a common ground of the ever-intensifying conflict between the Islamic world and the United States that has aroused due to the Islamic fundamentalism and Puritanical-capitalistic rational thought of the USA. He correlates alleged containment of self- 
criticism in Islam and the blandness of Puritanism and Capitalism of the United States. Religious and political and orthodoxies are restraining their intellectual legacies. Majid vows for the retrieval of the progressive tradition of Islam as an alternative to encounter the forces like rampant commercialism and political messianism. Majid considers facts to show that Islam is not the root cause of terrorism; however, it is a strategy to stand against globalization with the intention to restore the practice of Islamic intellectual and theological dissent. He demonstrates the reformist initiatives of Muslims like Nobel Prize winner Shirine Ebadi or King Mohammad VI to improve the rights of women. However, he includes the progressive strains in the Islamic fundamentalist movement as well. He also discusses about the Arab intellectuals like Richaid Benzine, Abdelmajid Charfi and Mohammad Talbi. He accepts the 19th century Orientalist paradigm of stagnation that Muslims are unaware about the event of modernity. Majid claims that it would be impossible to understand the culture and politics of the United States without its religious formation. He reckons the Puritanism at the bedrock of U.S. history, culture and political expression and develops a viewpoint of religious anti-secularist and moralist strains in Islam and American history. Islamism is the only democratic alternative to authoritarian regimes.

There is a conflict between the virtues of post-war 'liberism and social responsibility', 'the institutionalization of corporatism and religious conservativism'. Due to the U.S. abandonment of its promise and myths, the people were disheartened. The United States hardly has any other alternative but to call on its legendary sense of ingenuity to make a change in the economic model by reinforcing its social and cultural fabric. The 'heresy' or the anti-orthodox and institutional thinking is a vigorous act to be free from the tyranny of Sunni orthodoxy. For the sake of modernity, it would be no more than embracing the right critical method that ensures a society which doesn't punish the difference or proscribe intellectual pluralism. Christians and Muslims share a tradition of conservatism and rationalism that can bind them and both of them can have a generic link toward modernity.

Meghnad Desai (2007) primarily distinguishes Islamism from Islam by relating the former as a political ideology while later as a religion. Islamism is an ideology consists with a set of ideas related to political goals. On the other hand, Islam is a religion, a guiding model or a system of belief. Unlike Islam, Islamism is closer to the doctrines like Nationalism, Socialism, Communism or Anarchism and for that, Bin Laden's actions need to be analyzed with an ideological framework, and not on spiritual point of view. "We need to demarcate between Islam as a religion and the political use of the religion which is labeled Islamism" (Desai, 2007:6). Religion sometimes has some impact on civic, social and political institutions, but its focus always remains on maintaining a decent life to secure a place in heaven. The ideology is drawn from the totalistic explanations of history drawn from Islamic theology, which has a political aim to win the power over people.

Islamism wants to re-establish the caliphate, and brings forth a new terror to the modern world. He pointed this as more close to Communism. Desai says that 'Islamism' has three forms, (1) 'Moral Islamism', (2) 'National Islamism', and (3) 'Global Islamism'. 'Moral Islamism' that proposes a moral regeneration among Muslims. 'National Islamism' indicates a practical policy to assume power in a Muslim country to confer the tenets of Sharia. 'Global Islamism' aims to create a worldwide Muslim polity under a re-established caliphate and building a cohesive moral society under Islamic domination. Lord Desai pointed out the western media provided information related to the threats and actions of Osama Bin Laden and Al-Qaeda and the relations of Bush administration as well as the governments of the Philippines, Indonesia, Egypt, Russian and Western Europe. He considers that the response eventually ended with the formation of some contradictory policies. Policies should consider only the Global Islamism to protest. Thus, he advises a new form of analysis that can provide safe-effective policies for the well-being of the people. He also talks about a platform that can address the people who are left behind in the process of modernization and globalization. He outlines the desire of Global Islamism. He sets Bin Laden's 
argument in the context of the last one hundred years relating the collapse of the Ottoman Empire, the abolition of the caliphate, effects of the two World Wars on the Middle East - especially that on Arabia, the Palestine-Israel conflicts and the broader trends of modernization and globalization (Masoom, 2012). "Islamism" wants a reformed in Saudi Arabia, the destruction of American superpower and the formation of a world-wide ummah under a restored caliph.

The term "Jihad" is commonly regarded in the West to be referring to "holy war" on behalf of Islam. Literary, 'jihad' means 'effort' (Oxford Dictionary). Jihad can be defined as, "the spiritual, psychological and physical effort exerted by Muslims to be closer to God and thus achieve a just and harmonious society"(Brown, 2001). Jihad is a phenomenon of collective mobilization that often incorporates family members and childhood friends to the movement; it has become loose-knit and informal network after the destruction of al-Qaeda's sanctuary in Afghanistan (Sageman, 2008). There are three generations of Jihadis, who fought against the Soviets in Afghanistan, who trained with al-Qaeda in Afghanistan and who are fighting in Iraq (Hafez, 2007). Those who sacrifice themselves in jihad, do so due to believe in great heavenly rewards and to protest the conspiracy against Islam (Cook, 2007).

Jihad as a phenomenon is not unfamiliar to the modern day world; however, the aspect of jihad evolves throughout the history. Marc Sageman (2008) examines the evolution of Jihadi movement in the global context. He outlines the transformation of the al-Qaeda into a diffuse, loose-knit and informal network after the destruction of al-Qaeda's sanctuary in Afghanistan. This informal network is formed and expanded through ties of kinship and friendship and supports his argument by showing the tendency among the jihadis from Morocco to Yemen to incorporate family members and childhood associates to the movement. Thus, individuals go through the radicalization process collectively. Sageman's thesis is now regarded as the "halal theory of terrorism". Sageman denies that economic deprivation, brainwashing, naïveté, ignorance, lack of family responsibility and sexual frustration are the causes behind terrorism. He indicates that there, are four aspects of the radicalization process of Jihad, (1) moral outrage, (2) a perception of Islam under siege, (3) the resonance of moral

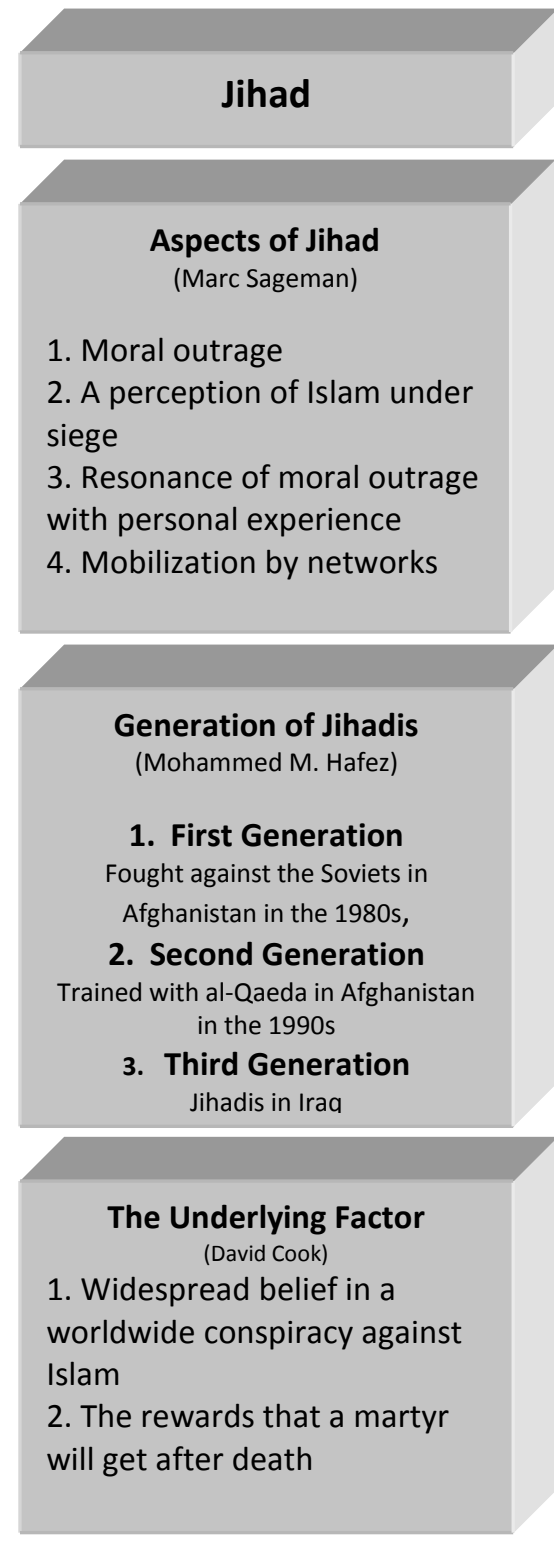

Fig. 5: Jihad and Jihadis outrage with personal experience and, (4) mobilization by networks. His framework helps to understand the phenomenon of collective mobilization in Islam and properly explain the two essential questions: who gets radicalized and why. The author also points out the importance of extremist ideology as well as the high prevalence of technical studies like engineering and medicine among jihadis.

Suicide bombing has become a common strategy in the name of Jihad. Mohammed M. Hafez (2007) discusses about the suicide bombings as a strategy for the insurgency in Iraq and outlines their ideology, history, causes and motivations. He says that suicide bombers are the 'Jihadi Salafis' or 'strivers for pious predecessors', a faction of the insurgency to interrupt the U.S foreign policy to fight against terrorism. Their goal is the establishment of an Islamic state in Iraq. Analyzing data on suicide bombing, The Suicide Bombers are mostly non-Iraqi Arabs from Saudi Arabia and other 
Arab countries. The social background of many suicide bombers indicates that they have faced unemployment, went through a process of criminalization, weak family ties or friendship, feeling of being hunted or no longer welcomed by their home or guest countries, predominantly in Europe.

Most of the suicide attacks have taken place in Iraq, targeting the fellow Muslims. Generally, there are two groups involved; one is Islamic Nationalists, the majority or insurgents, whereas the other is the Sunni extreme jihadi Salafis, mainly the ones who carry out suicide bombing. The "Ideological Ba'athists," is another group of the Salafis. They are mostly involved in supplying, funding, and providing intelligence to insurgencies, but not brave enough to serve as a suicide bomber. A majority of the population of Iraq is Shiite and Kurds who would not allow a victory of the jihadi Salafis. There are three generations of Jihadis, the first generation fought against the Soviets in Afghanistan in the 1980s, the succeeding generation trained with al-Qaeda in Afghanistan in the 1990s and the third generation is the jihadis in Iraq. The motive of the jihadis in Iraq is tantamount to spark a civil war and for that they attack the Shi'ites. He also noted that, the Wahhabism in Saudi Arabia is a form of Salifism as it holds a strong position against the Shi'ites.

Hafez concentrates on the networks that facilitate the whole phenomenon and explain the recruiting process of suicide bombers by applying a social movement approach. Suicide Bombers capitalize on the injustice faced by the Muslim world to legitimize their activities and rationalize suicide bombing. "Jihadists forge the myth of heroic martyrdom to motivate militants and newcomers to jihad to sacrifice themselves for heavenly rewards and to ease the shame of humiliation" (Hafez, 2007:20). The author also single outs their hatred of the Shiite because they consider the Shiite as them 'al-rafidah' or the rejection of Islam. While talking about the consequences of this suicide bombing, Dr. hafez considers the impact as not very consistent because of their target, lethality and psychological potency. Considering the history of suicide bombing to Japan in WWII, Lebanaon, Palestine and some other part of the world he asserts that, "Suicide terrorism is one of the means for weak groups to coerce strong opponents into making concessions or changing their policies" (Hafez, 2007:9). Often their primary aim is to demoralize the people of the targeted country and enhance their appeal.

David Cook (2007) presents a chronology of the development of martyrdom in the Muslim world and the diverse aspects of sacrificing the self. He defines the term martyrdom, examines the rewards that a martyr will get after death promised by the Qur'anic doctrine as well as Hadith and demonstrates various forms of martyrdom. However, the author agrees that "nowhere in the literature do we actually find an exact, agreed upon definition of martyrdom" (Cook, 2007:167). Cook's analysis begins with a brief review of Jewish and Christian martyrdoms and then elaborates the experiences of martyrdom in the formative period of Islam. He explores the broadening categories of martyrdom from the rudimentary sense of dying in the battlefield to the occurrences that are not necessarily leading towards death. Other than dying in the battlefield to defend the homeland, if a person dies due to fever, eaten by any wild animal, bitten by a toxic creature or killed by an autocratic ruler are also considered as a martyr. Husbands who behave properly with their wives and children, and the women who go on a righteous hajj are also martyrs. He also focuses on a different type of martyrdom, martyrs of love and demonstrates this genre mainly through the famous stories of Majnun and Layla as well as Jamil and Buthayna. Further, he deals with epic heroes who were literary and political martyrs in diverse places such as Persia, Turkey.

Cook points out that all different sectarian Islam, such as the Sunni, proto-Shi'ite, Kharijite, and 'Sufi martyrotogies', have their own distinct historical process of their formation. The medieval development of martyrdom in different Muslim countries like, Indonesia, Malaysia and some centers of Africa have got influenced by the local cultural formation. Cook describes the frequent mythical patterns of martyrdom and several associated motives with martyrdom. The motives include the apocalypse, expiation, the concluding exhortation through the martyr's death and his 
remembrance in different Islamic cultures. The leading figures or movements and theoretical ideas or practiced policy contributes to the martyrdom in contemporary radical Islam. These ideas and policy are the eventuality of the widespread belief in a worldwide conspiracy against Islam and the establishment of the state of Israel. All the modern anti-Islamic occurrences led the jihadi movement develops both an apologetic jihad and an operation of martyrdom that is the suicide attack.

\section{CONCLUSION}

Past few years produces various literatures on Islam that cover most of the areas related to it that intended to explain all aspects to seek a proper understanding of the current situation. This is because the modern day world politics is to the greater extent, being shaped by the incidents that are in a way or other is connected to Islam, or be more precise, related to the Middle East. Scholars in different fields, whether its political science, history, sociology, anthropology or even literature, attempt to explain Islam. Though to the lesser extent, their study is more diverse than integrated, a connection can be established. Political Islam has several faces that have a link with globalization and colonialism. All aspects of modern day politics, pluralism, parliamentary democracy and fundamentalism have been mainstreamed with Islam as a political system. Governing body of some countries like Senegal has made Islam a commodity for gaining privileges in business. Conversely, some other nations, like Africa have prepared their constitutions by following the 'Sufi tradition' of Islam. Making any state 'Islamic' or converting people Muslim requires changes in power relations, legal institutions, norms, rituals and belief system. Islamization often integrates with urbanization; however, it may not bring a good result especially for the women who are living in the West. Political ideology of Islam also has many faces, like moral Islamism, national Islamism and global Islamism. However, Islamism is concerned with establishing Islamic law in the state with an intention of opposing globalization. Sometimes, the violence is quite evident in the political Islam. Jihad is a brutal form of war because it affects the ordinary people. Suicide bombers also have a distinct point of view than that of the ordinary people. They are primarily driven by the afterlife rewards.

\section{Reference}

[1] Ahmed, Akbar (2007). Journey into Islam: The Crisis of Globalization. Brookings Institution Press.

[2] An-Na'im, Abdullahi Ahmed. 2006. African Constitutionalism and the Role of Islam. Philadelphia: University of Pennsylvania Press.

[3] Ayoob, Mohammed (2008). The Many Faces of Political Islam: Religion and Politics in the Muslim World. University of Michigan Press.

[4] Brown, Derek. 2001. "Attack and aftermath: a glossary of terms". Guardian. September 27.

[5] Cook, David (2007). Martyrdom in Islam, Themes in Islamic History. Cambridge, Cambridge University Press.

[6] Desai , Meghnad (2007). Rethinking Islamism: An Ideology of the New Terror. London: I. B. Tauris \& Co. Ltd.

[7] Feder, Don (2007). "Atheists Won't Save Europe", Published in GrasstopsUSA.com Thursday, April 19. Retrived on February 27, 2009, URL $<$

http://www.frontpagemag.com/Articles/Read.aspx?GUID=8DD1B06F-5870-4878-97706FCA118D0141>

[8] Federspiel, Howard M. (2007). Sultans, Shamans and Saints: Islam and Muslims in Southeast Asia. Honolulu: University of Hawai'i Press. 
[9] Firestone, Rueven (1999). Jihad: The Origin of Holy War in Islam, Oxford University Press.pg. 17

[10] Hafez, Mohammed M. (2007). Suicide Bombers in Iraq: the Strategy and Ideology of Martyrdom. Washington D.C.: United States Institute of Peace Studies.

[11] Lindley-Highfield, M. (2008). "'Muslimization", Mission and Modernity in Morelos: the problem of a combined hotel and prayer hall for the Muslims of Mexico'. Tourism Culture \& Communication, vol.8, no.2, 85-96.

[12] Majid, Anouar (2007). A Call for Heresy: Why Dissent is Vital to Islam and America. Minneapolis: University of Minnesota Press.

[13] Masoom, Muhammad Rehan. (2012). Structure of intellectual trend in recent researches on 'islam': an approach to consolidate the empirical studies. Jurnal Al-Tamaddun, 7(2), 89-103.

[14] McGinty, Anna Mansson (2006). Becoming Muslim: Western Women's Conversions to Islam. New York: Palgrave Macmillan.

[15] Ross, Eric (2006). Sufi City: Urban Design and Archetypes in Touba Rochester: U of Rochester P.

[16] Sageman, Marc (2008). Leaderless Jihad: Terror Networks in the Twenty-First Century. University of Pennsylvania Press.

[17] Soares, Benjamin F. (2005). Islam and the Prayer Economy: History and Authority in a Malian Town. Ann Arbor: University of Michigan Press. 